\title{
PGP Gene
}

National Cancer Institute

\section{Source}

National Cancer Institute. PGP Gene. NCI Thesaurus. Code C111791.

This gene may be involved in regulating oxygen transport. 